\title{
Bedrock Geology of the
}

Tiverton Quadrangle

Rhode Island-Massachusetts

By SAMUEL J. POLLOCK

GEOLOGY OF SELECTED QUADRANGLES IN RHODE ISLAND

GE OL O I A A S URVEY B ULLETIN 1158-D

Prepared in cooperation with the

Development Council of the

State of Rhode Island 
UNITED STATES DEPARTMENT OF THE INTERIOR

STEWART L. UDALL, Secretary

\author{
GEOLOGIGAL SURVEY \\ Thomas B. Nolan, Director
}




\section{CONTENTS}

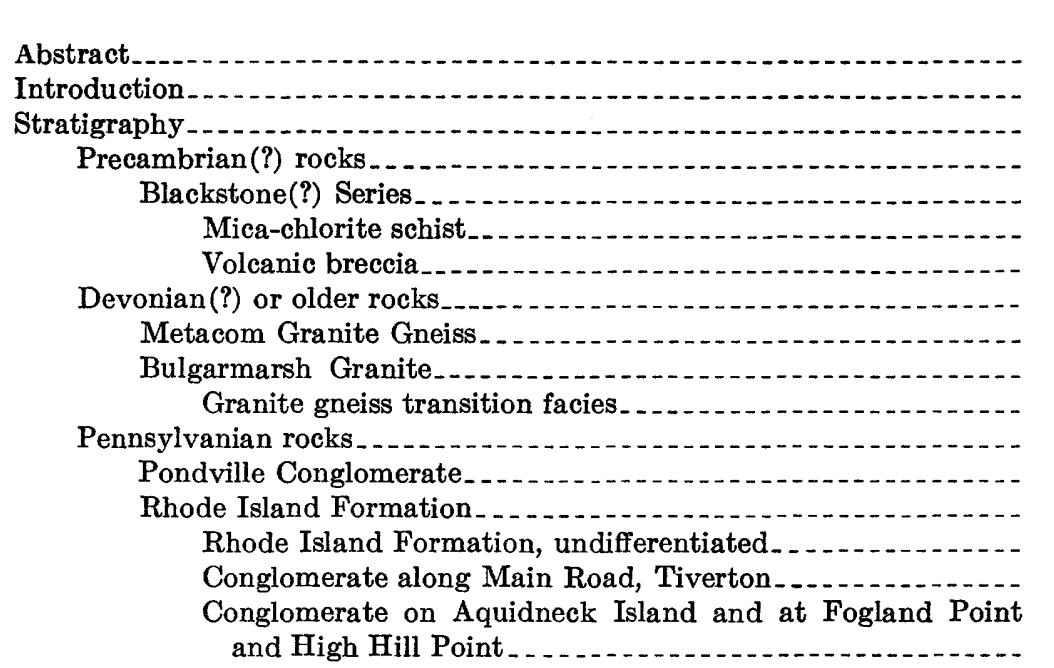

Regional structure....... 9

Pre-Pennsylvanian structures. 10

Folds . . .

Faults...

Foliation

Lineation

Pennsylvanian or post-Pennsylvanian structures............... 11

Folds . . . . . .

Faults__._. 11

Foliation and lineation. 11

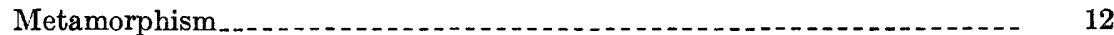

Pre-Pennsylvanian rocks.

Pennsylvanian rocks._. 13

Engineering and economic gelogy 13

References.... 15 


\section{ILLUSTRATION}

Plate 1. Geologic map of the Tiverton quadrangle, Rhode Island-

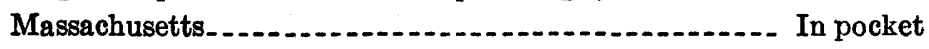

TABLE

TABLE 1. Dimensions of conglomerate pebbles 


\title{
GEOLOGY OF SELECTED QUADRANGLES IN RHODE ISLAND
}

\section{BEDROGK GEOLOGY OF THE TIVERTON QUADRANGLE RHODE ISLAND-MASSACHUSETTS}

\author{
By Samuel J. Pollock
}

\section{ABSTRACT}

The bedrock of the Tiverton 71/2-minute quadrangle, Rhode Island-Massachusetts, is of Precambrian(?), Devonian(?) or older, and Pennsylvania ages. The eastern half of the quadrangle is underlain by granite, granite gneiss, and schist of Devonian(?) or older age. The western half of the quadrangle is in the Narragansett basin, a topographic and structural trough that contains rocks mainly of Pennsylvanian age and occupies much of eastern Rhode Island.

The pre-Pennsylvanian schistose rocks have been assigned to the greenschist facies or the chloritoid almandine subfacies of the albite-epidote-amphibolite facies. Metamorphism had little effect on the pre-Pennsylvanian granitic rocks, one of which-the Metacom Granite Gneiss-appears to have originated by granitization, and another of which-the Bulgarmarsh Granite-appears to have had a magmatic origin.

In the Tiverton quadrangle, the Pennsylvanian rocks consist of sandstones, shales, and conglomerates, which have been folded into a complex synclinal structure and which unconformably overlie rocks of pre-Pennsylvanian age in most places. The metamorphic grade of the Pennsylvanian rocks is low.

\section{INTRODUCTION}

The Tiverton 71/2-minute quadrangle, Rhode Island-Massachusetts, is underlain by rocks of Precambrian (?), Devonian(?) or older, and Pennsylvanian ages (pl. 1). The western half of this area is in the Narragansett basin, a topographic and structural trough that occupies much of eastern Rhode Island and extends northeastward into Massachusetts (Emerson, 1917, p. 52-55). The eastern limit of the Narragansett basin is marked by an escarpment more than 100 feet high that extends southward for more than $31 / 2$ miles from the northern boundary of the quadrangle. The escarpment has resulted from differential resistance to erosion of the granite, gneiss, and schist of Devonian( (?) or older age (Emerson, 1917) and the adjacent rocks of the Narragansett basin, which are deformed sedimentary rocks of Pennsylvanian age.

Pleistocene glacial deposits cover much of the bedrock, especially in the southeastern part of the quadrangle. During the mapping in 
1955 , therefore, the location of contacts in these areas was based on topographic expression of the bedrock and composition of the drift. In contrast, bedrock outcrops are numerous along the west-facing escarpment of the Narragansett basin, along the shores of the Sakonnet River, and on many of the hills.

\section{STRATIGRAPHY \\ PRECAMBRIAN(?) ROCKS}

\section{BLACKSTONE(?) SHRIES}

Probably the oldest rocks of the Tiverton quadrangle are the micachlorite schist that crops out in several areas and the volcanic breccia exposed on Gould Island. These rocks are both correlated tentatively with the Blackstone Series of northern Rhode Island, a series that includes a great variety of metamorphosed sedimentary and volcanic rocks. The mica-chlorite schist in the vicinity of Brown Point was named the Little Compton Shales and assigned a pre-Carboniferous age by Shaler, Woodworth, and Foerste (1899, p. 281-283). Emerson (1917, map) grouped these rocks with the Marlboro Formation, Algonkian(?), of Massachusetts. Quinn, Ray, and Seymour (1949) assigned rocks of Emerson's Marlboro Formation in Rhode Island to the Blackstone Series of Precambrian(?) age, first described by Shaler, Woodworth, and Foerste $(1899$, p. 1, 4, 109). The bases for correlation of these rocks with the Blackstone Series are similarity of lithologic character, of metamorphic rank, and of structural discordance to the Pennsylvanian rocks of the Narragansett basin. These rocks are intruded by pre-Pennsylvanian granitic rocks.

\section{MICA-CHLORITE SCHIST}

Mica-chlorite schist underlies much of the area on the east side of the Sakonnet River and is chiefly exposed in the vicinity of Sin and Flesh Brook, northeast of Tiverton Four Corners, and east and south of Brown Point. The rocks of these areas are similar enough to be grouped together, although minor local differences occur.

The main type of mica-chlorite schist is a green to gray fine-grained thin-bedded rock, whose schistosity generally parallels its bedding. Quartz, biotite, and chlorite are the chief constituents; muscovite, epidote, calcite, and hornblende are locally abundant. Minor and accessory constituents are albite, microcline, microperthite, zircon, apatite, sphene, magnetite, ilmenite, and garnet.

The most extensive exposures are along the shore south of Brown Point where the bedding of the mica-chlorite schist is thin and even. Locally the schist contains abundant limestone beds less than an inch thick. At Brown Point and eastward, the bedding and schistosity 
strike northeast, apparently parallel to the contact of the schist and the overlying Pennsylvanian rocks, although in some places the bedding and schistosity are highly contorted and sheared, as on the road that runs east from Main Road, approximately 4,500 feet south of the intersection of Peckham Road and Main Road.

On the east side of Borden Brook, northeast of Tiverton Four Corners, the schist contains beds of amphibolite, epidote-hornblende schist, and quartzite as much as 50 feet thick. The schistosity and bedding strike northeast, in general parallel to the contact of the adjacent granite and at an angle to the contact of the Pennsylvanian sedimentary rocks.

\section{VOLCANIC BRECCIA}

The dark-green to white volcanic breccia exposed on Gould Island is chiefly composed of angular poorly sorted fragments of fine-grained gneiss and schist, as much as $9 \mathrm{~cm}$ in length but commonly about $2 \mathrm{~cm}$, in a finer grained groundmass of similar mineralogical composition. Most of the larger fragments are of light-colored gneiss composed chiefly of quartz and feldspar, but some are dark and consist largely of biotite and chlorite. A few uniformly fine-grained beds of quartzmica schist, as much as 15 feet thick, contain quartz, orthoclase, biotite, chlorite, epidote, and muscovite; the minor constituents are ilmenite, magnetite, apatite, calcite, and sphene. Aplite and granite dikes, and veins of quartz and epidote, cut these rocks. The schistosity and bedding strike approximately north and dip almost vertically. Poor sorting, angularity of fragments, and variation of material suggest a volcanic origin for this unit.

\section{DEVONIAN(?) OR OLDER ROCKS}

\section{MWTACOM GRANITE GNEISS}

The Metacom Granite Gneiss, described first by Quinn and Springer (1954) in the Bristol quadrangle, is exposed in the vicinity of Highland Avenue, Tiverton, north of Nannaquaket Pond. Exposures to the north in the Fall River quadrangle suggest that the Metacom may also underlie Island Park, although no bedrock is exposed there.

This unit is a gray to pink medium-grained granite gneiss containing abundant small ovoidal aggregates of biotite. Lineation is less conspicuous than in the same formation in the Bristol quadrangle. The granite gneiss is composed chiefly of quartz (44 percent), microcline and microperthite ( 30 percent), albite ( 17 percent), muscovite (6 percent), and biotite and chlorite (3 percent). Minor and accessory constituents are zircon, apatite, sphene, magnetite, ilmenite, rutile, and epidote. Small aplite dikes are common in the gneiss of both the Tiverton and the Bristol quadrangles. 
The Metacom Granite Gneiss appears to have originated by granitization of the mica-chlorite schist, as relicts of the schist are contained in the gneiss and the gradation between the mica-chlorite schist and the Metacom Granite Gneiss is marked by a progressive increase of feldspar content from the schist to the gneiss. A similar relation was found in the Bristol quadrangle (Quinn and Springer, 1954).

\section{BULGARMARSH GRANITE}

The Bulgarmarsh Granite of Devonian(?) or older age is here designated as a new formation and is named for exposures along Bulgarmarsh Road, approximately 2,300-3,400 feet northeast of the intersection with Main Road. It is also abundantly exposed south of Bulgarmarsh Road to Tiverton Four Corners and underlies most of the remainder of the east half of the quadrangle, but exposures are sparse along the east margin and in the southeast.

The Bulgarmarsh Granite is pink to gray, coarse grained, and foliated in most places. The character of the foliation varies from place to place; in some places the foliation is the result of a parallelism of elongated quartz grains and in others, a parallelism of biotite and chlorite flakes. The most obvious foliation is caused by the biotite and chlorite. Although the strike of the foliation is variable, it is commonly northeast.

The Bulgarmarsh Granite consists of quartz (36-66 percent), microperthite and microcline (17-38 percent), albite $\mathrm{An}_{3-7}$ (7-32 percent), biotite and chlorite (0.2-5 percent), muscovite (0.2-13 percent), and minor magnetite, ilmenite, leucoxene, rutile, apatite, zircon, epidote, garnet, sphene, and allanite. The albite contains many small crystals of epidote, suggesting that it has been derived from a somewhat more calcic plagioclase. Small aplite dikes and quartz veins are common in the granite.

A pre-Pennsylvanian age of the Bulgarmarsh Granite is shown by the unconformable relation between the granite and the Pennsylvanian sedimentary rocks. In the Fall River quadrangle, just north of the Tiverton quadrangle, G. H. Springer (written communication) has demonstrated petrographically the similarity between granite pebbles in the basal Pennsylvanian rocks and the underlying granite, which is continuous with the Bulgarmarsh Granite.

The Bulgarmarsh Granite is shown to be younger than the micachlorite schist of the Blackstone(?) Series: (1) by inclusions of the schist in the granite, (2) by its intrusive contact with the schist at Sin and Flesh Brook, and (3) by a gradational contact with the schist at several places in the central part of the quadrangle, represented by the transition facies. 
The Bulgarmarsh Granite appears to be of magmatic origin, as indicated by its intrusive contact with the mica-chlorite schist at Sin and Flesh Brook, where schist inclusions have been rotated in the granite, and schist layers have been spread apart by the granite. Schist inclusions oriented in various directions are found in many outcrops of the Bulgarmarsh Granite. The foliation in the Bulgarmarsh Granite evidently represents an original flow structure and parallels the schistosity of the mica-chlorite schist in many places where the flow of the intruding granite was controlled by the structure of roof pendants and inclusions. In other places, the granite foliation is oblique to the schistosity of the mica-chlorite schist.

The Bulgarmarsh Granite was included with the Dedham Granodiorite by Emerson (1917, p. 172-177). Emerson realized, however, that several rock varieties composed his Dedham Granodiorite. The Bulgarmarsh Granite is not to be correlated with typical Dedham Granodiorite, which is more than 20 miles from the Tiverton area, because published descriptions (Loughlin and Hechinger, 1914, p. 49 ; LaForge, 1932 , p. 26) show andesine to be the principal plagioclase feldspar in the Dedham, whereas albite $\left(\mathrm{An}_{3-7}\right)$ is the principal plagioclase in the Bulgarmarsh. Foliation is rare in the Dedham (Emerson, 1917, p. 176) and common in the Bulgarmarsh.

\section{GRANITE GNEISS TRANSITION FACIES}

Where outcrops of the Bulgarmarsh Granite can be found near the mica-chlorite schist in the central part of the quadrangle, a transition zone commonly exists between the granite and the schist. Excellent exposures of this transition facies are found south of Borden Brook, about 2,500 feet east-northeast of Tiverton Four Corners. This zone is as much as 600 feet wide. The middle of the zone typically consists of granite gneiss having approximately the following composition: quartz (63 percent), microcline and microperthite (14 percent), albite (10 percent), muscovite ( 8 percent), biotite and chlorite ( 5 percent), and minor apatite, epidote, sphene, magnetite, zircon, and garnet. Much of the microcline and microperthite occur as elongated pink porphyroblasts, averaging $25 \mathrm{~mm}$ in length. The well-developed foliation in this transition zone is parallel to that in both the adjacent schist and the granite. This fact and the gradation in mineral composition from granite to schist through the zone indicates that the zone originated by emanations from the Bulgarmarsh Granite soaking into and partly replacing the mica-chlorite schist.

East and southeast of Tiverton Four Corners are several other areas of the transition facies. 


\section{PENNSYLVANIAN ROCKS}

The western half of the Tiverton quadrangle is underlain by sedimentary rocks of the Narragansett basin that have been assigned to the Pennsylvanian System on the basis of plant fossils found at several localities (Knox, 1944; Lesquereux, 1889; Packard, 1889; Round, 1924, 1927; Shaler and others, 1899). These rocks include beds of sandstone, shale, conglomerate, and meta-anthracite. Abrupt lateral and vertical variations are characteristic of these beds and also of Pennsylvanian rocks elsewhere in the basin. Although the Pennsylvanian rocks of the Narragansett basin have been divided by previous authors (Shaler and others, 1899, pl. 31; Emerson, 1917, pl. 10) into several formations, it is not feasible to differentiate them in the Tiverton quadrangle owing to the general cover of glacial drift. In the northern part of this quadrangle the Pennsylvanian rocks have been divided into two formations, the Pondville Conglomerate and the overlying Rhode Island Formation (Emerson, 1917, p. 52-55). In addition, two conglomerate beds in the Rhode Island Formation have been mapped separately. South of White Wine Brook, the Pondville Conglomerate may be present but covered.

The Pennsylvanian rocks of the Narragansett basin are younger than the underlying igneous and metamorphic rocks that border the Narragansett basin because boulders and pebbles of some of the underlying rocks are found in the conglomerates in the lower part of the Rhode Island Formation.

\section{PONDVILLE CONGLOMERATE}

The Pondville Conglomerate is exposed only from the east shore at the mouth of Quaket River discontinuously southward to a point approximately a thousand feet south of Bulgarmarsh Road. The conglomerate may pinch out to the south, and it is probably less than 500 feet thick at Quaket River. This unit was called the Tiverton Arkose by Shaler, Woodworth, and Foerste (1899, p. 378). Petrographic study has revealed no feldspar, however, so that the term arkose is inappropriate.

The rock is a fine-grained light- to dark-gray quartzitic granule conglomerate, containing pebbles of smoky quartz as much at $5 \mathrm{~mm}$ in diameter. Individual beds of the conglomerate range in thickness and lateral extent and are interbedded with gray to black sandstone and shale. The chief mineral constituents of the formation are quartz and muscovite; minor constituents are chloritoid, garnet, chlorite, magnetite, ilmenite, sphene, zircon, graphite, leucoxene, biotite, and calcite. 
The Pondville Conglomerate lies directly on the Bulgarmarsh Granite approximately 900 feet northwest of the intersection of Main Road and Bulgarmarsh Road. The contact is not easily recognized because the conglomerate directly overlying the granite consists of granitic debris that after having been thoroughly weathered in place, thus destroying the feldspars, was transported only a short distance. The pre-Pondville weathering of the Bulgarmarsh Granite here compounds the difficulty of distinguishing between the two rocks. The irregularities in the contact between the Pennsylvanian rocks and the underlying rocks are the result of original topographic irregularties and later folding and faulting.

The Pondville Conglomerate is the lowermost Pennsylvania formation in the northern part of the area. It may be present and covered south of the outcrop area, or the Rhode Island Formation may rest directly on the pre-Pennsylvanian rocks.

\section{RHODE ISLAND FORMATION}

The Rhode Island Formation, the thickest and most widely exposed formation of the Narragansett basin, underlies most of the western half of the Tiverton quadrangle. Although much of this area is mapped as Rhode Island Formation, undifferentiated, two types of conglomerate have been mapped.

\section{RHODE ISLAND FORMATION, UNDIFFERENTIATED}

The Rhode Island Formation, undifferentiated, consists of irregularly interbedded sandstone, shale, conglomerate, and meta-anthracite. The chief mineral constituents of the formation are quartz and muscovite; biotite and chlorite are locally abundant. Lithic fragments are common. Minor constituents are magnetite, ilmenite, graphite, sphene, plagioclase, microperthite, apatite, zircon, pyrite, and garnet. The chief mineral constituents of the sandstone and conglomerate are quartz and feldspars; the shaly beds mainly contain quartz, biotite, and muscovite. Because of the difficulties in structural and stratigraphic interpretation, no accurate estimate of thickness of the Rhode Island Formation in the Tiverton quadrangle could be made.

Although most of the sandstone and shale is gray to black, thin beds of red shale and sandstone are exposed south of the outlet of Nonquit Pond in the belt east of the Sakonnet River and south of Portsmouth Park in the area west of the river. Many sandstone beds show crossbedding. Some sandstone beds contain angular fragments of shale.

The conglomerate contains pebbles of gray quartzite and gray to black sandstone, and fragments of black shale, most of which are less than 3 inches long. Exposures of conglomerate can be seen at a few places on the east bank of the Sakonnet River, such as (1) along the 
shore between Brown Point and the outlet on Nonquit Pond and (2) on the shore just north of High Hill Point. Conglomerate can be seen also on the west shore of the Sakonnet River south of Portsmouth Park and east of Glen Road.

Beds of impure meta-anthracite and graphite crop out approximately 900 feet south of the outlet of Nonquit Pond, south of Portsmouth Park, and on the shore east of Glen Road.

Plant fossils occur in shoreline exposures south of the outlet of Nonquit Pond, south of Portsmouth Park, and east of Glen Road (Shaler and others, 1899, pl. 31). Obolus-bearing quartzite pebbles derived from Upper Cambrian or Lower Ordovician rocks (Shaler and others, 1899 , p. 382 , pl. 31 ; Walcott, 1898 , p. 327-328) are found in all the conglomerates of the Rhode Island Formation. Some of the Obolusbearing pebbles were observed as beach pebbles on the east shore of the Sakonnet River south of Brown Point. The source of these quartzite pebbles is problematical as no quartzite bedrock containing fossil Oboli is known in this general area.

\section{CONGLOMERATE ALONG MAIN ROAD, TIVERTON}

The conglomerate exposed along Main Road is distinguished from other conglomerate of the Rhode Island Formation by the size and kinds of the pebbles. These pebbles have an average length of 3 inches and a maximum of 12 inches. They are smaller than the pebbles of the conglomerate mapped on Aquidneck Island, Fogland Point, and High Hill Point; they are larger than the pebbles in several conglomerate beds included in the Rhode Island Formation undifferentiated. The predominant type of pebble in this conglomerate, as in the other conglomerates of the area, is quartzite; this conglomerate also contains pebbles of Bulgarmarsh Granite and mica-chlorite schist. Most of the conglomerates also contain a few pebbles of sandstone, shale, conglomerate, and gneiss.

The matrix of the conglomerate and the interbeds of sandstone are quartz, muscovite, biotite, and chlorite with minor amounts of magnetite, ilmenite, sphene, apatite, plagioclase, microperthite, zircon, and garnet. The bedding in the conglomerate is generally irregular and not obvious in some outcrops; it is most plainly indicated by sandstone interbeds.

In most outcrops the elongation of the pebbles is slightly east of north; the plunge in places is to the north and in other places it is to the south or horizontal.

The proximity of this conglomerate to outcrops of pre-Pennsylvanian rocks indicates that it is one of the early sedimentary deposits of the Pennsylvanian System of the Narragansett basin. 
Data are insufficient for an accurate estimate of the thickness of the conglomerate exposed along Main and Neck Roads.

\section{CONGLOMERATE ON AQUIDNECK ISLAND AND AT FOGLAND POINT AND HIGH HILL POINT}

On Aquidneck Island and at Fogland Point, and High Hill Point similar beds of coarse conglomerate, containing interbedded sandstone and shale, are exposed. These conglomerates are light to dark gray and contain elongated pebbles and boulders whose longest dimension arerages 6 inches but that may be as long as 3 feet. These boulders are chiefly quartzite, but sandstone, shale, porphyry, and conglomerate boulders are common. Interbedded layers and lenses of gray to darkgray sandstone and shale are commonly as much as 5 feet thick but locally are as thick as 50 feet. A few thin beds of red shale are present. Bedding is irregular, and some crossbedding is found in the interbedded sandstone. The conglomerate matrix and the interbedded units are quartz, biotite, chlorite, muscovite, and minor magnetite, zircon, apatite, and rutile. As determined from the dip of the bedding and the width of outcrop, the conglomerate exposed in the vicinity of Wapping Road and Old Mill Lane is probably at least 500 feet thick, that exposed along the shore south of Black Point is probably 320 feet thick, that exposed at High Hill Point is probably 200 feet thick, and the conglomerate bed exposed at Fogland Point is probably at least 120 feet thick.

The pebbles of these conglomerate beds are elongated to about the same extent and are oriented in approximately the same directions as the pebbles of the conglomerate along Main Road, Tiverton.

\section{STRUCTURAL GEOLOGY}

\section{REGIONAL STRUCTURE}

The western half of the Tiverton quadrangle includes part of the southeastern corner of the Narragansett basin, a synclinorium that trends northward in eastern Rhode Island and northeastward in Massachusetts. The eastern half of the quadrangle is underlain by igneous and metamorphic rocks of pre-Pennsylvanian age. The trends of the foliation, bedding, and contacts of the pre-Pennsylvanian rocks are mostly northeast, in sharp discordance with the northward trends of the beds of the Pennsylvanian rocks of the Narragansett basin. This discordance shows that the Pennsylvanian rocks were deposited unconformably on the pre-Pennsylvanian rocks; the unconformity is one of the major structural features of the quadrangle.

In pre-Pennsylvanian time the mica-chlorite schist and the volcanic breccia were folded and metamorphosed and also intruded by the Bulgarmarsh Granite. This deformation and igneous activity probably 
was part of the Acadian orogeny that affected parts of New England. The Pennsylvanian rocks of the Narragansett basin, however, were deformed by the Appalachian orogeny (Eardley, 1951, p. 171).

\section{PRE-PENNSYIVANIAN STRUCTURES}

The pre-Pennsylvanian layered rocks were folded, probably faulted, and made schistose during the Acadian orogeny; however, only small disconnected masses of these rocks survived the effects of intrusion, erosion, and burial by later deposits. As a result, only the trends of bedding and schistosity in these isolated units can be ascertained, and little can be determined about the folds and faults that must have been present.

\section{Fouds}

As shown by the strike of the beds along the shore north of Church Point, fold axes in the mica-chlorite schist trend approximately north. At Brown Point and to the east, some fairly close folding is indicated by the dips of the beds, and fold axes trend northeast, about parallel to the contact with the Pennsylvanian rocks.

\section{FAULTS}

Because of the scarcity of outcrops, it was not possible to map any faults.

\section{FOLIATION}

Foliation of the mica-chlorite schist is parallel to the bedding of the schist, as exposed along the shore north of Church Point. In some of the exposures east of Main Road and south of Peckham Road, cleavage cuts the bedding at high angles. The foliation of the micachlorite schist is discordant to the bedding of the Pennsylvanian rocks north of Nannaquaket Pond and in the vicinity of Tiverton Four Corners.

The foliation of the volcanic breccia at Gould Island trends north or slightly west of north and there are vertical dips or steep westward dips.

In the Bulgarmarsh Granite, folation trends mostly northeast and is oblique to the margin of the Narragansett basin.

\section{IINEATION}

In the mica-chlorite schist exposed along the shore north of Church Point, a fairly well developed lineation plunges southeastward at angles of less than $28^{\circ}$. 


\section{PENNSYLVANIAN OR POST-PENNSYLVANIAN STRUCTURES}

\section{Fords}

Although most of the Pennsylvanian rocks are irregular and discontinuous, some of the conglomerate beds have considerable continuity and help to determine the general structure of the Narragansett basin. The conglomerate in Tiverton indicates a generally simple structure with the beds striking northward and dipping steeply westward into the synclinorium of the Narragansett basin; however, because of irregularities of deposition, crossbeds in the conglomerate are abundant and give divergent strike and dip readings in many places. Another conglomerate extends approximately 2 miles southward from Black Point into the Sakonnet Point quadrangle. This conglomerate is steeply overturned, as indicated by crossbedding, and appears to be on the eastern limb of a syncline, the western limb of which is exposed along Wapping Avenue.

The less competent shale and sandstone are marked by many small folds. At High Hill Point and north of Brown Point, the small folds are overturned toward the west, in agreement with the fold inferred from the conglomerate south of Black Point and along Wapping Avenue. At many places, however, the small folds do not seem to be in agreement with any plan of folding; this may be due to the incompetence of the rock or perhaps to incompleteness of exposure.

The rocks of the Narragansett basin apparently were deformed by a compressive force that acted in an east-west direction and folded the rocks into their present complex synclinal structure. Locally, the beds diverge from the general northward trending structure, probably at the noses of plunging anticlines and synclines.

\section{FAULTS}

Many minor faults are exposed, but direct evidence for major faults is absent. Indirect evidence suggests that the volcanic breccia of Gould Island is faulted upward. Evidence concerning the nature of this structure is completely lacking in the Tiverton quadrangle, but G. H. Springer (written communication) proposed two faults to explain a similar situation in the Fall River quadrangle to the north. One of these faults, if extended, would lie in the Sakonnet River east of Gould Island, and the other would extend through Island Park and run just west of Gould Island. Evidence is insufficient, however, to eliminate folding as an alternative.

\section{FOLIATION AND IINEATION}

Schistosity is present in shale and sandstone, although it is not conspicuous in most places. Conglomerate generally has a conspicu- 
ous foliation and lineation that results from the deformed pebbles. Tectonic forces that folded these rocks deformed the pebbles into triaxial ellipsoids. The longest axes constitute a lineation; the longest and the intermediate axes constitute a foliation plane.

The Purgatory Conglomerate of the Newport quadrangle has long been known for its "stretched" pebbles. In the Tiverton quadrangle, the author measured the long, intermediate, and short axes of 100 pebbles (table 1) at each of three localities-High Hill Point, Black Point, and the cove east of the intersection of Indian and Howland (printed Rowland on the map) Avenues, Middletown. A statistical analysis of variance indicates no significant difference between the amount of stretching of the pebbles at the three localities.

TABLE 1.-Dimensions of conglomerate pebbles

\begin{tabular}{|c|c|c|c|c|}
\hline \multirow{2}{*}{ Locality } & \multicolumn{3}{|c|}{ Average dimension of axis (inches) } & \multirow{2}{*}{$\begin{array}{l}\text { Ratio between axes (long: } \\
\text { intermediate: short) }\end{array}$} \\
\hline & Long & Intermediate & Short & \\
\hline $\begin{array}{l}\text { High Hill Point } \\
\text { Black Point } \\
\text { Howland Avenue. }\end{array}$ & $\begin{array}{l}6.5 \\
7.9 \\
7.8\end{array}$ & $\begin{array}{l}2.8 \\
3.4 \\
3.3\end{array}$ & $\begin{array}{l}\text { 1. } 5 \\
\text { 1. } 7 \\
1.8\end{array}$ & $\begin{array}{l}\text { 4. } 11: 1.78: 1 \\
\text { 4. } 46: 1.96: 1 \\
\text { 4. } 15: 1.76: 1\end{array}$ \\
\hline
\end{tabular}

In most places in the Pennsylvanian conglomerates of the Tiverton quadrangle, the direction of elongation of the pebbles is approximately north, parallel to the strike of the bedding, and the axis of elongation is horizontal or has a plunge that is generally less than $10^{\circ}$. Long axes of pebbles are commonly parallel to the fold axes. The plane formed by the long and intermediate axes of the pebbles here is generally not parallel to the bedding and probably corresponds to the axial planes of the folds.

Foliation in the conglomerate could not be measured in all places where the lineation of pebbles was measured because of the nature of the exposures and because in places the ratio between the short and intermediate axes approaches unity.

\section{METAMORPHISM}

All the rocks of the Tiverton quadrangle have been affected by metamorphism.

\section{PRE-PENNSYLVANIAN ROCKS}

The pre-Pennsylvanian rocks were metamorphosed before the Pennsylvanian rocks were deposited. Metamorphism produced micachlorite schist containing hornblende, epidote, garnet, biotite, chlorite, muscovite, and ilmenite in the sedimentary rocks composed of volcanic debris and light-colored gneisses, and epidote, biotite, chlorite, musco- 
vite, magnetite, and ilmenite in the volcanic breccia of Gould Island. These mineral assemblages indicate that the grade of regional metamorphism in these rocks is relatively low. Rocks in the vicinity of Brown Point have been assigned to the biotite-chlorite subfacies of the greenschist facies, a slightly lower metamorphic grade than the remainder of the mica-chlorite schist and the volcanic breccia which are in the chloritoid-almandine subfacies of the albite-epidote-amphibolite facies.

The Metacom Granite Gneiss probably was formed by granitization, as suggested by Quinn and Springer (1954). Where granitization was incomplete, relicts of the schist are found in the gneiss, or a transition facies was formed, an example of which is found between the Bulgarmarsh Granite and the mica-chlorite schist in the central part of the quadrangle. The Pennsylvanian or later regional metamorphism appears to have had a negligible effect on the mineralogical and textural characteristics of the pre-Pennsylvanian rocks.

\section{PENNSYIVANIAN ROCKS}

Metamorphism of the Pennsylvanian sedimentary rocks elongated the conglomerate pebbles, developed schistosity and lineation in the shaly and sandy beds, and changed the coaly beds to meta-anthracite and graphite. It created such minerals as chloritoid, garnet, muscovite, biotite, chlorite, and ilmenite in the Pondville Conglomerate and muscovite, biotite, chlorite, ilmenite, and garnet in the Rhode Island Formation. Of particular interest in the Rhode Island Formation are porphyroblasts of biotite, which are found in black shale outcrops on the shore south of Portsmouth Park. On the basis of the minerals formed by the metamorphism of the Pennsylvanian rocks, these rocks are all assigned to the biotite-chlorite subfacies of the greenschist facies representing low-grade metamorphism.

\section{ENGINEERING AND ECONOMIC GEOLOGY}

Bedrock formations of the Tiverton quadrangle have had little economic value. Crushed rock for road metal was taken from a small quarry west of McCurry Point in the summer of 1955. Here, shale of Pennsylvanian age, suitable for use on private roads and driveways where traffic is light, has been quarried. The most promising sources of crushed rock in the quadrangle are the Metacom Granite Gneiss, east of Highland Avenue, and the Bulgarmarsh Granite, north and northeast of the intersection of Bulgarmarsh Road and Main Road. There are fairly high cliffs and extensive exposures at both of these localities. Smaller amounts of crushed rock might be obtained from many other outcrops of the granite that are smaller, 


\section{D14 GEOLOGY OF SELECTED QUADRANGLES IN RHODE ISLAND}

lower, and more distant from good roads. A minor amount of crushed rock has been taken from the Pennsylvanian conglomerates of the Tiverton quadrangle, and a much larger amount has been quarried at the Paradise Rocks area of the Prudence Island quadrangle, half a mile west of the southwest corner of the Tiverton quadrangle. Most of the Pennsylvanian sandstone and shale, the transition facies, and the mica-chlorite schist are too soft and schistose to be suitable for crushed rock.

The Bulgarmarsh Granite, the Metacom Granite Gneiss, the volcanic breccia on Gould Island, and the Pennsylvanian conglomerates are difficult to excavate and are strong enough to stand in vertical faces and to sustain heavy loads. The transition facies, the micachlorite schist, and the Pennsylvanian sandstones and shales are softer and more easily excavated. Parts of the formations will stand in vertical cuts, but other parts tend to break readily into slabs and to slide along closely spaced bedding and schistosity planes.

The amount of drift over the bedrock has an important effect on excavation. Most of the bedrock of Aquidneck Island, except along the shore, is completely covered. Almost any excavation there deeper than 3 or 4 feet, however, will expose very weak and locally graphitic shale. On the east side of the Sakonnet River, bedrock is exposed or lies at shallow depths in the areas indicated on the map as closely spaced bedrock outcrops. In the rest of the quadrangle, the mantle of drift is probably about 20 feet thick but may be thicker than 50 feet in places.

Thin and discontinuous beds of meta-anthracite are exposed in the Tiverton quadrangle but are of no economic value at present. Two mines have been worked. Case's mine, located on the west side of East Main Road, Portsmouth, approximately 1,400 feet south of the intersection of Chase Road and East Main Road, was worked at various times from 1808 to 1853 and is reported to have produced about 100,000 tons of coal (Shaler and others, 1899, p. 206-207). An open-pit graphite mine was worked (presumably before 1900) about 300 yards south of the outlet of Nonquit Pond on the east bank of the Sakonnet River. Schrader, Stone, and Sanford (1917, p. 269) reported that 200 tons of graphite was mined here for use in the manufacture of paint. Drilling by the U.S. Bureau of Mines in 1945 (Toenges and others, 1948) on Aquidneck Island in the vicinity of the Portsmouth mines, to the west and northwest of the Tiverton quadrangle, disclosed only thin discontinuous meta-anthracite beds of no economic value.

Resources of sand and gravel are rather limited in the Tiverton quadrangle. Three of the largest areas of sand and gravel in the 
quadrangle are the Island Park area, the Sapowet Point area, and the area between the Amicable Church and the Nonquit School. In the summer of 1955 a small gravel pit was in operation about 2,800 feet northwest of the intersection of East Road and Crandall Road.

It should be noted here that the nature of the bedrock influences the composition and physical characteristics of the surficial deposits. Gravels in the Narragansett basin generally contain pebbles derived from weak shale and sandstone, and the till of this area is very clayey, compact, and impervious. Outside of the basin, however, the gravels commonly contain stronger pebbles and boulders derived from the underlying crystalline bedrock, and the associated till is sandier and loose textured.

The greatest ground-water yields are from wells in sand and gravel. Wells drilled in bedrock are successful only if they penetrate water-filled fissures, as none of the bedrock has more than a negligible amount of intergranular porosity. Fissures, joints, foliation planes, and miscellaneous fractures are haphazardly distributed throughout the bedrock; consequently their location at depth cannot be predicted. Yields from wells intersecting these fissures generally are adequate only for small households. In the Pennsylvanian beds, particularly the shale that commonly contains pyrite, ground water may be unsuitable for use because of dissolved iron salts and other undesirable chemical compounds. The ground-water resources of the Tiverton quadrangle were being studied in detail by the Water Resources Division of the U.S. Geological Survey in 1962.

\section{REFERENCES}

Eardley, A. J., 1951, Structural geology of North America : New York, Harper \& Bros., $624 \mathrm{p}$.

Emerson, B. K., 1917, Geology of Massachusetts and Rhode Island: U.S. Geol. Survey Bull. 597, 289 p.

Knox, A. S., 1944, A Carboniferous flora from the Wamsutta formation of southeastern Massachusetts: Am. Jour. Sci., v. 242, p. 130-138.

LaForge, Laurence, 1932, Geology of the Boston area, Massachusetts: U.S. Geol. Survey Bull. 839, p. 26-27.

Lesquereux, Leo, 1889, Fossil plants of the coal measures of Rhode Island: Am. Jour. Sci. 3d ser., v. 37, p. 229-230.

Loughlin, G. F., and Hechinger, L. A., 1914, An unconformity in the Narragansett basin of Rhode Island and Massachusetts: Am. Jour. Sci., 4th ser., v. 38, p. $45-64$.

Packard, A. S., 1889, Recent discoveries in the Carboniferous flora and fauna of Rhode Island: Am. Jour. Sci., 3d ser., v. 37, p. 411.

Quinn, A. W., Ray, R. G., and Seymour, W. L., 1949, Bedrock geology of the Pawtucket quadrangle, Rhode Island-Massachusetts: U.S. Geol. Surrey Geol. Quad. Map GQ-1. 


\section{D16 GEOLOGY OF SELECTED QUADRANGLES IN RHODE ISLAND}

Quinn, A. W., and Springer, G. H., 1954, Bedrock geology of the Bristol quadrangle and vicinity, Rhode Island-Massachusetts: U.S. Geol. Survey Geol. Quad. Map GQ-42.

Round, E. M., 1924, Correlation of fossil floras of Rhode Island and New Brunswick: Bot. Gazette, v. 78, p. 116-118.

Round, E. M., 1927, Correlation of coal floras of Henry County, Missouri, and the Narragansett basin: Bot. Gazette, v. 83, p. 61-69.

Schrader, F. C., Stone, R. W., and Sanford, Samuel, 1917, Useful minerals of the United States: U.S. Geol. Survey Bull. 624, 412 p.

Shaler, N. S., Woodworth, J. E., and Foerste, A. F., 1899, Geology of the Narragansett basin : U.S. Geol. Survey Mon. 33, 402 p.

Toenges, A. L., Turnbull, L. A., Neale, Arthur, and others, 1948, Investigation of meta-anthracite in Newport and Providence Counties, R.I.; petrography, chemical characteristics, and geology of deposits: U.S. Bur. Mines Rept. Inv. $4276,37 \mathrm{p}$.

Walcott, C. D., 1898, Note on the brachiopod fauna of the quartzite pebbles of the Carboniferous conglomerates of the Narragansett basin, Rhode Island: Am. Jour. Sci., 4th ser., v. 6, p. 327-328. 